Hewlett B (1996) Cultural diversity among African Pygmies. In: Kent $S$ (ed) Cultural diversity among twentieth-century foragers. Cambridge University Press, Cambridge, pp 215244

Horai S, Hayasaka K (1990) Intraspecific nucleotide sequence differences in the major noncoding region of human mitochondrial DNA. Am J Hum Genet 46:828-842

Jorde LB, Bamshad MJ, Watkins WS, Zenger R, Fraley AE, Krakowiak PA, Carpenter KD, et al (1995) Origins and affinities of modern humans: a comparison of mitochondrial and nuclear genetic data. Am J Hum Genet 57:523538

Menozzi P, Piazza A, Cavalli-Sforza LL (1978) Synthetic maps of human gene frequencies in Europe. Science 201: 786-792

Mountain JL, Hebert JM, Bhattacharyya S, Underhill PA, Ottolenghi C, Gadgil M, Cavalli-Sforza LL (1995) Demographic history of India and mtDNA-sequence diversity. Am J Hum Genet 56:979-992

Piazza A, Rendine S, Minch E, Menozzi P, Mountain J, Cavalli-Sforza LL (1995) Genetics and the origin of European languages. Proc Natl Acad Sci USA 92:58365840

Richards M, Côrte-Real H, Forster P, Macaulay V, WilkinsonHerbots H, Demaine A, Papiha S, et al (1996) Paleolithic and Neolithic lineages in the European mitochondrial gene pool. Am J Hum Genet 59:185-203

Rogers AR, Harpending H (1992) Population growth makes waves in the distribution of pairwise genetic differences. Mol Biol Evol 9:552-569

Ruiz-Linares A, Nayar K, Goldstein D, Hebert JM, Seielstad MT, Underhill PA, Feldman MW, et al (1996) Geographical clustering of human Y-chromosome haplotypes. Ann Hum Genet 60:401-408

Semino O, Passarino G, Brega A, Fellous M, Santachiara-Benerecetti AS (1996) A view of the Neolithic demic diffusion in Europe through two $\mathrm{Y}$ chromosome-specific markers. Am J Hum Genet 59:964-968

Slatkin M, Hudson RR (1991) Pairwise comparisons of mitochondrial DNA sequences in stable and exponentially growing populations. Genetics 129:555-562

Sokal RR, Rohlf FJ (1981) Biometry. WH Freeman, San Francisco

Underhill PA, Jin L, Zemans R, Oefner PJ, Cavalli-Sforza LL (1996) A pre-Columbian Y chromosome-specific transition and its implications for human evolutionary history. Proc Natl Acad Sci USA 93:196-200

Vigilant L, Pennington R, Harpending H, Kocher TD, Wilson AC (1989) Mitochondrial DNA sequences in single hairs from a southern African population. Proc Natl Acad Sci USA 86:9350-9354

Vigilant L, Stoneking M, Harpending H, Hawkes K, Wilson AC (1991) African populations and the evolution of human mitochondrial DNA. Science 253:1503-1507

Address for correspondence and reprints: Dr. L. L. Cavalli-Sforza, Department of Genetics, MS-5120, Stanford University School of Medicine, Stanford, CA 94305-5120. E-mail: cavalli@lotka.stanford.edu

(C) 1997 by The American Society of Human Genetics. All rights reserved. 0002-9297/97/6101-0038\$02.00
Am. J. Hum. Genet. 61:251-254, 1997

\section{Reply to Cavalli-Sforza and Minch}

\section{To the Editor:}

In a recent paper (Richards et al. 1996), we used a phylogeographic approach to infer that most $(>85 \%)$ of the mtDNA control region (D-loop) variation in presentday Europeans has an ancient ancestry within Europe, coalescing during the Upper Paleolithic. This seems to be in contrast with earlier principal-component analyses of nuclear-gene frequencies in Europe, widely interpreted as evidence for a substantial Neolithic settlement from southwest Asia, which overwhelmed the Mesolithic hunter-gatherers. This apparent conflict has engendered the response by Cavalli-Sforza and Minch. They make criticisms of our treatment of the data in particular and of the reliability of mitochondrial control-region sequences in general, both of which criticisms we will address below. It is worth noting at the outset, however, their new suggestion that the proportion of the variation accounted for by the first principal component $(26 \%)$ is "probably not very far" from the proportion of genes contributed by Neolithic newcomers to the European gene pool. Were this correct, it might seem that there could be little room for debate, since we could agree that the genetic contribution of the newcomers, while not insignificant, was relatively minor. However, there is more to the issue than this.

With regard first to their specific criticisms of our paper, it is precisely because there is little of interest to be learned from population-based comparisons using a single locus that we adopted a genealogical approach. There was - and apparently still is - a basic misunderstanding concerning the way in which mtDNA and Y-chromosome sequences should be analyzed for population studies. Traditionally, nuclear-allele frequency data have been the target of investigation, but, because recombination operates on such data in every generation, such analyses are inevitably restricted to coarsegrained summary statistics at the population level (diversity measures, population trees, principal-component maps, etc.). The resulting loss of information is then compensated in part by taking a large number of such loci into consideration. With mtDNA (or, for that matter, any other single locus), this approach is bound to be rather uninformative, and it is no surprise that earlier reports of European mtDNA diversity (Pult et al. 1994; Bertranpetit et al. 1995) were unable to detect significant structure. Table 2 in our earlier paper testifies to the futility of applying diversity measures between populations to mtDNA. We evidently did not emphasize this clearly enough in our paper, leading Cavalli-Sforza and Minch to miss our point and to reiterate this unhelpful test scenario by use of table 4 in our previous paper. 
Our own approach is very different. It has been argued within evolutionary biology, for at least a decade, that mtDNA is "not just another molecular marker" (Avise et al. 1987, p. 516), in that it offers the currently unrivaled opportunity for estimation of intraspecific phylogenies (both gene trees and, potentially, coalescent trees) and to detect geographical patterns in distributions and ages of clusters or clades. This approach was promoted by Allan Wilson and his colleagues (e.g., see Cann et al. 1987) and has been aptly termed "phylogeography" by Avise et al. (1987). The work of Templeton et al. (1995 [and earlier references therein]), our work (Bandelt et al. 1995; Forster et al. 1996; Richards et al. 1996), and the work of several others (Torroni et al. 1996 [and references therein]; Ward and Valencia 1996 [and references therein]; Harding et al. 1997) can be situated within this phylogeographic tradition.

A phylogenetic analysis also allows one to evaluate the information content of different stretches and positions in the mitochondrial genome, relative to an envisaged time depth. Although Cavalli-Sforza and Minch dismiss the possibility that mtDNA sequence variation contains much genuine information, a high level of noise would in fact have easily been detected by our phylogenetic-network method. It is, for instance, quite evident that the second hypervariable segment of the control region offers little phylogenetic information in the case of European sequences, since a handful of positions appear to be extreme mutational hot spots (Aris-Brosou and Excoffier 1996; Torroni et al. 1996). By contrast, control-region sequences from the first segment, especially when additionally supported by restriction-site data from the entire mitochondrial genome, are highly informative - at least within a time scale of the past 100,000 years or so. Cavalli-Sforza and Minch thus confound a perceived inadequacy of the mitochondrial control region with the genuine futility of applying certain analytical tools (such as population trees, principal component maps, and so on) to mtDNA for reconstruction of historical processes of human dispersal. Their attempts to explain the seeming homogeneity of European mtDNA therefore lead to ad hoc explanations about the nature of mtDNA variation in human populations, such as when "heteroplasmy," "high female migration," and "hypergamy" are invoked to postulate a depression of genetic distances in non-Africans. Yet, all the evidence to date for humans (Bendall et al. 1996; Howell et al. 1996; Parsons et al. 1997) points to a relatively rapid fixation mechanism for new mitochondrial mutations, so that the intermediate state of heteroplasmy does not persist for more than a few generations. As for different mating patterns between the sexes, we have always been clear that maternal-lineage reconstruction using mtDNA has nothing direct to say about the contribution of males to the gene pool. Parallel studies using Y-chromosome variation will be more helpful in addressing these issues than are assumptions about the unknown reproductive behavior of prehistoric populations.

The differences between ourselves and Cavalli-Sforza and his colleagues should not allow us to miss what we have in common. We can agree that pure indigenism is mistaken and that the Neolithic newcomers left a definite mark in the European gene pool, albeit as a minority. This is suggested by both mitochondrial and Y-specific markers (Semino et al. 1996) and no longer hinges entirely on a particular interpretation of synthetic maps for nuclear frequency data. Indeed, the synthetic maps for Europe that have been provided by Cavalli-Sforza et al. (1994) are not incompatible with the scenario outlined in our paper. However, there is no good reason for believing that the first principal component in Europe is due entirely to Neolithic rather than to, say, early Upper Paleolithic settlement or even a mixture of the two. It is hard to see why principal components and migrations (or demic diffusion processes) should correspond to each other in a one-toone fashion. Two or more migrations may contribute to a single component, and it may well be that the first principal component in Europe is a palimpsest of early Upper Paleolithic, Neolithic, and perhaps other expansions from southwest Asia. In this context, there is an interesting qualitative similarity between the radiocarbon map for the spread of the Neolithic (e.g., see fig. 1 of Cavalli-Sforza and Minch) and that for settlement in the early Upper Paleolithic (see fig. 1). Finally, there is no good reason either for the suggestion of CavalliSforza and Minch that the variation accounted for by the first principal component $(\sim 26 \%)$ is directly related to the proportion of the European gene pool contributed by the newcomers, because the extent of variation described by the first principal component depends not only on the number of incoming settlers but also on their genetic distance from the native populationand even on subsequent population movements.

Contrary to some of the most detailed considerations of the archaeological evidence in recent years (e.g., see Whittle 1996), the mtDNA data suggest that new colonization of Europe from southwest Asia did indeed occur during the Neolithic, as Cavalli-Sforza and his colleagues proposed (Menozzi et al. 1978; Ammerman and Cavalli-Sforza 1984). Nevertheless, it seems likely that their interpretation underestimates the Mesolithic contribution. Furthermore, the model of demic diffusion by means of a wave of advance may also give the wrong impression about the nature of Neolithic colonization. Archaeologists have pointed out that the radiocarbon maps on which the model was originally based were constructed on the assumption of a uniform "Neolithic package." This does not hold true for most of the maps' sites outside 


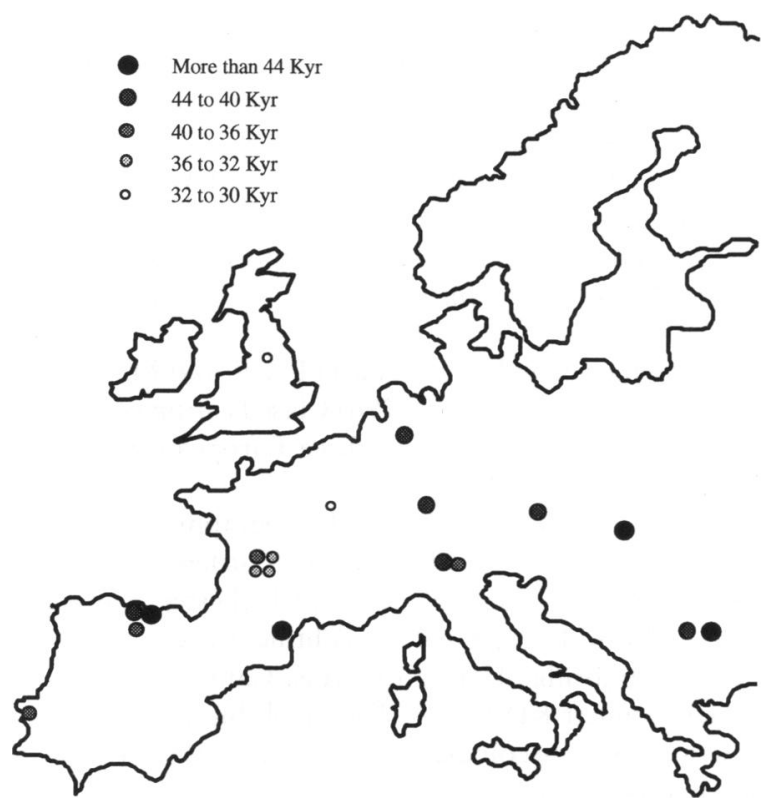

Figure 1 Radiocarbon evidence for the spread of the early Upper Paleolithic in Europe, including all assemblages with radiocarbon dates earlier than 30,000 years before the present, regardless of their specific taxomic facies. Dates were taken from the publications listed below and from a database assembled by S. W. G. Davies. The chronological data support an east-west movement (Djindjian 1991; Koslowski 1992; Mellars 1992; Hahn 1993). The earliest dates are from the Balkans and the middle Danube basin (Haesaerts 1990; Koslowski 1992). Early dates in the Mediterranean (Bartolomei 1992; Bischoff et al. 1989; Straus 1994) suggest an initial, rapid spread of the Aurignacian, restricted to the northern Mediterranean coast, although isolated examples of early dates in Germany and Belgium may also indicate an early expansion up the Rhine (Hahn 1993; Otte 1990) by way of extension from movement along the Danube corridor (Koslowski 1992). The two routes of expansion are strikingly similar to the pattern of the later spread of the Neolithic.

the central LBK (Linienbandkeramik) zone, and when this is taken into account the rate of spread is more punctuated (Zvelebil 1989; Thomas 1996). This receives some support from the mitochondrial data, in which the probable Neolithic lineages occur typically in only $10 \%-15 \%$ of total lineages and do not show southeast-northwest clines. Taken together with the presence of geographically specific lineages within the Neolithic cluster, this suggests a rapid penetration from the southeast, both westward and northwestward, followed by a much more gradual intermixing with the numerically dominant indigenous Mesolithic inhabitants. This view is also in line with paleoecological evidence (Willis and Bennett 1994), which shows no immediate environmental impact associated with the earliest radiocarbon dates for the European Neolithic.

Referring to the demic and cultural components of the Mesolithic-Neolithic transition, Ammerman $(1989$, p. 163) has suggested that "the real challenge for the archaeologist must be to evaluate the relative importance of the two different modes in various regions of Europe." Classical genetic analyses have given us limited purchase on this problem. The phylogeographic approach, pioneered with the use of mtDNA and increasingly being applied to the $\mathrm{Y}$ chromosome and other nuclear loci, seems to us a more promising route to take.

MARTIN RichaRds, ${ }^{1}$ VINCENT MACAUlay, ${ }^{1}$ Bryan Sykes, ${ }^{1}$ Paul PetTitT, ${ }^{2}$ Robert Hedges, ${ }^{2}$ PETER FORSTER, ${ }^{3}$ AND HANS-JÜGEN BANDELT ${ }^{4}$

${ }^{1}$ Department of Cellular Science, Institute of Molecular Medicine, and ${ }^{2}$ Research Laboratory for Archaeology, University of Oxford, Oxford; and ${ }^{3}$ Heinrich-Pette-Institut für Experimentelle Virologie und Immunologie, and ${ }^{4}$ Mathematisches Seminar, University of Hamburg, Hamburg

\section{Acknowledgments}

We thank S. W. G. Davies (University of Cambridge) for access to unpublished radiocarbon dates. This work was supported by the Wellcome Trust.

\section{References}

Ammerman AJ (1989) On the Neolithic transition in Europe: a comment on Zvelebil and Zvelebil (1988). Antiquity 63: $162-165$

Ammerman AJ, Cavalli-Sforza LL (1984) The Neolithic transition and the genetics of populations in Europe. Princeton University Press, Princeton

Aris-Brosou S, Excoffier L (1996) The impact of population expansion and mutation rate heterogeneity on DNA sequence polymorphism. Mol Biol Evol 13:494-504

Avise JC, Arnold J, Ball RM, Bermingham E, Lamb T, Neigel JE, Reeb CA, et al (1987) Intraspecific phylogeography: the mitochondrial DNA bridge between population genetics and systematics. Annu Rev Ecol Syst 18: 489-522

Bandelt H-J, Forster P, Sykes BC, Richards MB (1995) Mitochondrial portraits of human populations using median networks. Genetics 141:743-753

Bartolomei G, Broglio A, Cassoli PF, Castelletti L, Cattani L, Cremaschi M, Giacobini G, et al (1992) La Grotte de Fumane: un site aurignacien au pied des Alpes. Preist Alpina 28:131-179

Bendall KE, Macaulay VA, Baker JR, Sykes BC (1996) Heteroplasmic point mutations in the human mtDNA control region. Am J Hum Genet 59:1276-1287

Bertranpetit J, Sala J, Calafell F, Underhill PA, Moral P, Comas D (1995) Human mitochondrial DNA variation and the origin of Basques. Ann Hum Genet 59:63-81

Bischoff JL, Soler N, Maroto J, Julia R (1989) Abrupt Mousterian/Aurignacian boundary at c. $40 \mathrm{kyr}$ BP: accelerator 14C dates from l'Arbreda cave (Catalunya, Spain). J Arch Sci 16:563-576 
Cann RL, Stoneking M, Wilson AC (1987) Mitochondrial DNA and human evolution. Nature 325:31-36

Cavalli-Sforza LL, Menozzi P, Piazza A (1994) The history and geography of human genes. Princeton University Press, Princeton

Djindjian F (1991) Les origines du peuplement aurignacien en Europe. In: Banesz L, Kozlowski J (eds) Aurignacien en Europe et au Proche Orient: 12eme Colloque Organise par la Commision 8 de la UISPP. Institut Archeologique del'Academie Slovaque, Bratislava, pp 136-154

Forster P, Harding R, Torroni A, Bandelt H-J (1996) Origin and evolution of Native American mtDNA variation: a reappraisal. Am J Hum Genet 59:935-945

Haesaerts P (1990) Nouvelles recherches au gisement de Willendorf (Basse Autriche). Bull Inst R Sci Nat Belg (Sci Terre) 60:203-218

Hahn J (1993) L'origine du Paleolitique Superieur en Europe centrale: les datations C14. In: Cabrera-Valdes V (ed) El origen del hombre moderno en el suroeste de Europa. UNED, Madrid, pp 61-80

Harding RM, Fullerton SM, Griffiths RC, Bond J, Cox MJ, Schneider JA, Moulin DS, et al (1997) Archaic African and Asian lineages in the genetic ancestry of modern humans. Am J Hum Genet 60:772-789

Howell N, Kubacka I, Mackey DA (1996) How rapidly does the human mitchondrial genome evolve? Am J Hum Genet 59:501-509

Kozlowski JK (1992) The Balkans in the Middle and Upper Palaeolithic: the gate to Europe or a cul-de-sac? Proc Prehist Soc 58:1-20

Mellars PA (1992) Archaeology and the population dispersal hypothesis of modern human origins in Europe. Philos Trans R Soc Lond [Biol] 337:225-234

Menozzi P, Piazza A, Cavalli-Sforza LL (1978) Synthetic maps of human gene frequencies in Europeans. Science 201: 86-792

Otte M (1990) From the Middle to Upper Palaeolithic: the nature of the transition. In: Mellars PA (ed) The emergence of modern humans: an archaeological perspective. Edinburgh University Press, Edinburgh

Parsons TJ, Muniec DS, Sullivan K, Woodyatt N, AllistonGreiner R, Wilson MR, Berry DL, et al (1997) A high observed substitution rate in the human mitochondrial DNA control region. Nat Genet 15:363-367

Pult I, Sajantila A, Simanainen J, Georgiev O, Schaffner W, Pääbo S (1994) Mitochondrial DNA sequences from Switzerland reveal striking homogeneity of European populations. Biol Chem Hoppe Seyler 375:837-840

Richards M, Côrte-Real H, Forster P, Macaulay V, WilkinsonHerbots H, Demaine A, Papiha S, et al (1996) Paleolithic and Neolithic lineages in the European mitochondrial gene pool. Am J Hum Genet 59:185-203

Semino O, Passarino G, Brega A, Fellous M, Santachiara-Benerecetti AS (1996) A view of the Neolithic demic diffusion in Europe through two Y chomosome-specific markers. Am J Hum Genet 59:964-968

Straus LG (1994) Upper Palaeolithic origins and radiocarbon calibration: more new evidence from Spain. Evol Anthol 3: 194-198

Templeton AR, Routman E, Phillips CA (1995) Separating population structure from population history: a cladistic analysis of the geographical distribution of mitochondrial DNA haplotypes in the tiger salamander, Ambystoma tigrinum. Genetics 140:767-782

Thomas J (1996) The cultural context of the first use of domesticates in continental central and northwest Europe. In: Harris DR (ed) The origins and spread of agriculture and pastoralism in Eurasia. UCL Press, London, pp 310-322

Torroni A, Huoponen K, Francalacci P, Petrozzi M, Morelli L, Scozzari R, Obinu D, et al (1996) Classification of European mtDNAs from an analysis of three European populations. Genetics 144:1835-1850

Ward RH, Valencia D (1996) Phylogeographic variability in traditional societies. In: Chadwick D, Cardew G (eds) Variation in the human genome. Wiley, Chichester, England

Whittle A (1996) Europe in the Neolithic: the creation of new worlds. Cambridge University Press, Cambridge

Willis KJ, Bennett KD (1994) The Neolithic transition-fact or fiction? palaeoecological evidence from the Balkans. Holocene 4:326-330

Zvelebil M (1989) On the transition to farming in Europe, or what was spreading with the Neolithic: a reply to Ammerman (1989). Antiquity 63:379-383

Address for correspondence and reprints: Dr. Martin Richards, Department of Cellular Science, Institute of Molecular Medicine, John Radcliffe Hospital, Headington, Oxford OX3 9DS, United Kingdom. E-mail: mrichard@worf .molbiol.ox.ac.uk

(C) 1997 by The American Society of Human Genetics. All rights reserved. 0002-9297/97/6101-0039\$02.00

Am. J. Hum. Genet. 61:254-255, 1997

\section{Nonparametric Linkage Tests Are Model Free}

To the Editor:

I followed with interest the recent exchange between Greenberg et al. (1996, 1997) and Farrall (1997). A major point of contention is whether affected-sib-pair (ASP) and other nonparametric linkage tests are really model free. Greenberg et al. (1997) contend that, because such tests are equivalent to LOD score tests under particular genetic models, they in fact implicitly assume a model and are "hardly model free in the usual understanding of that phrase." Farrall argues that the tests are nonparametric in the sense that they do not require that a particular model be specified a priori. Who is right?

The argument can be settled by referring to standard statistical literature on nonparametric statistics. Lindgren $(1968$, p. 400) defines "distribution free" (or "model free," or "nonparametric") tests as "procedures involving a statistic whose distribution (at least 